[Agr. Biol. Chem., Vol. 26, No. 3, p. 167 174, 1962]

\title{
Studies on the Pentose Isomerases of Lactic Acid Bacteria
}

\author{
Part VII. Chromatography of Pentose Isomerases*
}

\author{
By Kei Yamanaka \\ Laboratory of Microbiology, Faculty of Agriculture, Kagawa Unituersity, Kagawa \\ Received October 5, 1961
}

\begin{abstract}
Column chromatographic procedures for the purification of pentose isomerases were carried out. Cation and anion exchange resins were not suitable because of their low exchange capacities and instability of the enzyme at acidic $\mathrm{pH}$ range. But the isomerases were successfully purified by DEAE-cellulose column chromatography with high recovery $(85 \sim$ $90 \%$ ). Using a Tris buffer, $\mathrm{KCl}$ concentration was increased in gradient. D-Xylose isomerase was eluted at $\mathrm{pH} 7.0$ at $0 \sim 0.2 \mathrm{M} \mathrm{KCl}$, and $\mathrm{L}$-arabinose isomerase at $\mathrm{pH} 8.0$ at $0 \sim 0.4 \mathrm{M} \mathrm{KCl}$. The purified isomerases, $\mathrm{D}$-xylose isomerase and $\mathrm{L}$-arabinose isomerase, both required manganese ions specifically for their activities.
\end{abstract}

\section{INTRODUCTION}

Pentose isomerases (D-xylose and L-arabinose isomerases) which catalyze the interconversion of aldopentoses and corresponding ketopentoses were found in several bacteria ${ }^{1 \sim 11}$. L-Arabinose isomerase from Lactobacillus plantarum, a homofermenter, was purified 7.7 fold by Heath et al. in the specific activi$\mathrm{ty}^{7)}$, and $\mathrm{D}$-xylose and L-arabinose isomerases from heterofermenters were also purified to about 8 fold in the specific activity ${ }^{12)}$.

\footnotetext{
* Presented at the Annual Meeting of the Agricultural Chemical Society of Japan at Hukuoka, Japan (April 1, 1961).

1) S. Mitsuhashi, and J. O. Lampen, J. Biol. Chem., 204, 1011

2) J. O. Lampen, Abstr. Proc. Am. Chem. Soc., 44c (1954); Personal communication (Sept. 15, 1960).

3) R.M. Hochster and R.W. Watson, J. Am. Chem. Soc., 75, 3284 (1953); Arch. Biochem. Biophys., 48, 120 (1954).

4) R. W. Slein, J. Am Chem. Soc., 77, 1663 (1955).

5) E. S. Kline and L.S. Baron, Arch. Biochem. Biophys., 66, 128 (1957).

6) D. B. Burma, Y. Takagi and P.Z. Smyrniotis, Federation Proc.,

7) E. C. Heath, B. L. Horecker, P.Z. Smyrniotis and Y. Takagi, J. Biol. Chem., 231, 1031 (1958).

8) F.J. Simpson and W.A. Wood, J. Am. Chem. Soc., 78, 5452 (1956).

9) U. Z. Littauer, B. E. Volcani and E. D. Bergmann, Biochim. Biophys. Acta, 18, 523 (1955)

10) K. Yamanaka, This Journal, 22, 299 (1958).

11) K. Yamanaka, ibid., 24, 305, 310 (1960).

12) K, Yamanaka, ibid, , 25, 272 (1961)
}

In the present paper, further purifications of the enzyme using column chromatography were carried out from the heterofermenters grown in a pentose-medium containing $5 \times$ $10^{-3} \mathrm{M} \mathrm{MnSO}_{4}$.

\section{METHODS}

\section{Culture.}

D-Xylose and L-arabinose isomerases were obtained from the cells of Lactobacillus brevis and $L$. gayonii grown in $\mathbf{D}$-xylose or $\mathrm{L}$-arabinose, respectively ${ }^{12}$. In order to increase the yield of the enzyme, the cultural medium was modified as reported previously ${ }^{13)}$. Microorganisms were grown for 16 hours, at which time the enzyme activity was the highest (Table I).

\section{Preparation of Enzymes.}

Partial purification of isomerase from pentosegrown cells was carried out as reported in the previous paper $^{12)}$ with several modifications. Precipitate by ammonium sulfate at 0.6 to 0.9 saturation was dissolved in $0.05 \mathrm{M}$ Tris* buffer ( $\mathrm{pH} 7.4$ for $\mathrm{D}$-xylose isomerase, $\mathrm{pH} 8.0$ for L-arabinose isomerase) and

13) K. Yamanaka and T. Higasihara, This Journal, 26, 162 (1962) * The following abbreviations are used: Tris, Tris-(hydroxymethyl) aminomethane ; EDTA, disodium salt of ethy lenediamine tetraacetic acid CM-cellulose, carboxymethyl-cellulose; DEAE-cellulose, diethylaminoethyl cellulose ; FMN, flavin mononucleotide ; and FAD, flavin adenine dinucleotide, 
Table I. Effect of Cultural Time on Isomerase Production

\begin{tabular}{|c|c|c|c|c|c|c|}
\hline \multirow{2}{*}{$\begin{array}{l}\text { Culture } \\
\text { (hr.) }\end{array}$} & \multirow{2}{*}{$\begin{array}{l}\text { Cell growth } \\
\left(\text { O.D. }{ }_{530}\right)\end{array}$} & \multirow{2}{*}{$\begin{array}{l}\text { Cell yield } \\
(\mathrm{g} / 3 \mathrm{l})\end{array}$} & \multirow[b]{2}{*}{$\begin{array}{l}\text { Enzyme } \\
\text { preparation }\end{array}$} & \multirow[b]{2}{*}{ Protein (mg) } & \multicolumn{2}{|c|}{$\mathrm{D}$-Xylose isomerase } \\
\hline & & & & & $\begin{array}{l}\text { Specific } \\
\text { activity }\end{array}$ & Total units \\
\hline 12 & 0.77 & 7.0 & $\left\{\begin{array}{l}\text { Crude extracts } \\
\left(\mathrm{NH}_{4}\right)_{2} \mathrm{SO}_{4} 0.6 \sim 0.9 \text { sat. }\end{array}\right.$ & $\begin{array}{l}332 \\
50.4\end{array}$ & $\begin{array}{l}10.3 \\
29.1\end{array}$ & $\begin{array}{l}3415 \\
1455\end{array}$ \\
\hline 16 & 0.87 & 10.0 & $\left\{\begin{array}{l}\text { Crude extracts } \\
\left(\mathrm{NH}_{4}\right)_{2} \mathrm{SO}_{4} 0.6 \sim 0.9 \text { sat. }\end{array}\right.$ & $\begin{array}{l}480 \\
54.0\end{array}$ & $\begin{array}{r}7.8 \\
33.4\end{array}$ & $\begin{array}{l}3755 \\
1810\end{array}$ \\
\hline 18 & 0.91 & 9.4 & $\left\{\begin{array}{l}\text { Crude extracts } \\
\left(\mathrm{NH}_{4}\right)_{2} \mathrm{SO}_{4} \quad 0.6 \sim 0.9 \text { sat. }\end{array}\right.$ & $\begin{array}{l}483 \\
58.4\end{array}$ & $\begin{array}{r}5.2 \\
30.1\end{array}$ & $\begin{array}{l}2540 \\
1750\end{array}$ \\
\hline 22 & 0.96 & 8.0 & $\left\{\begin{array}{l}\text { Crude extracts } \\
\left(\mathrm{NH}_{4}\right)_{2} \mathrm{SO}_{4} 0.6 \sim 0.9 \text { sat. }\end{array}\right.$ & $\begin{array}{l}378 \\
55.7\end{array}$ & $\begin{array}{r}4.5 \\
26.8\end{array}$ & $\begin{array}{l}1710 \\
1490\end{array}$ \\
\hline 24 & 0.97 & 7.8 & $\left\{\begin{array}{l}\text { Crude extracts } \\
\left(\mathrm{NH}_{4}\right)_{2} \mathrm{SO}_{4} 0.6 \sim 0.9 \text { sat. }\end{array}\right.$ & $\begin{array}{l}328 \\
43.5\end{array}$ & $\begin{array}{r}3.4 \\
18.8\end{array}$ & $\begin{array}{r}1100 \\
820\end{array}$ \\
\hline 45 & 0.98 & 7.4 & $\left\{\begin{array}{l}\text { Crude extracts } \\
\left(\mathrm{NH}_{4}\right)_{2} \mathrm{SO}_{4} 0.6 \sim 0.9 \text { sat. }\end{array}\right.$ & $\begin{array}{l}347 \\
50.5\end{array}$ & $\begin{array}{l}0.0 \\
0.0\end{array}$ & $\begin{array}{l}\text { trace } \\
\text { trace }\end{array}$ \\
\hline
\end{tabular}

L. brevis, D-xylose isomerase.

dialyzed against $0.0025 \mathrm{M}$ Tris buffer ( $\mathrm{pH}$ 7.4) at $6^{\circ} \mathrm{C}$ for 40 hours. Further purification was carried out with acetone. The $\mathrm{pH}$ of ammonium sulfate fraction was adjusted to 4.8 to 5.0 with $0.05 \mathrm{M}$ acetic acid. Acetone previously cooled at $-20^{\circ} \mathrm{C}$ was added dropwise to the fraction at $-10 \sim-15^{\circ} \mathrm{C}$ with stirring and precipitates were collected at acetone concentrations of $0 \sim 40 \%$ and $40 \sim 60 \%$. Isomerase was extracted with chilled water from these precipitates. After centrifugation, the clear supernatant was obtained which was used mainly in this experiment. The precipitate was reextracted with $0.05 \mathrm{M}$ Tris buffer, but only a trace of enzyme activity was recovered. Typical data for preparation of enzymes are shown

Table II. Preparation of Pentose Isomerase*

A. D-Xylose isomerase (L. brevis)

Fraction Volume Protein Specific Total Yield

\begin{tabular}{lllrrr}
\multicolumn{1}{c}{ Fraction } & $(\mathrm{ml})$ & $(\mathrm{mg})$ & activity & utits & $(\%)$ \\
Crude extracts & 50 & 480 & 7.8 & 3755 & - \\
$\begin{array}{l}\text { Mn-treated } \\
\text { Ammonium sulfate }\end{array}$ & 50 & 237 & 12.5 & 2960 & 79.0 \\
$\begin{array}{l}\text { ppt. 0.6 0.9 sat. } \\
\text { Acetone 40 60\% }\end{array}$ & 70.6 & 54 & 33.4 & 1805 & 51.0 \\
ppt. & 7.0 & 23.3 & 75.9 & 1330 & 35.4
\end{tabular}

B. L-Arabinose isomerase (L. gayonii)

Fraction Volume Protein Specific Total Yield

$\begin{array}{lccrcr} & (\mathrm{ml}) & (\mathrm{mg}) & \text { activity } & \text { units } & (\%) \\ \text { Crude extracts } & 50 & 255 & 5.9 & 1670 & - \\ \begin{array}{l}\text { Mn-treated } \\ \text { Ammonium sulfate }\end{array} & 50 & 162 & 13.1 & 2115 & 126 \\ \begin{array}{l}\text { ppt. 0.6 0.9 sat. } \\ \text { Acetone 40 60\% }\end{array} & 9.0 & 24.3 & 46.6 & 1110 & 66.5 \\ \text { ppt. } & 6.0 & 14.5 & 85.5 & 1024 & 61.4\end{array}$

* 31,16 hours old culture. in Table II. Fractionation with ethanol at various $\mathrm{pH}$ range was not successful. Enzyme preparations were stored at $-20^{\circ} \mathrm{C}$.

\section{Chromatography on Ion Exchange Resins.}

Cation and anion exchange resins were bufferized with citrate-phosphate buffer at $\mathrm{pH} 4.0$ to 8.0 according to the method of Hirs, Moore and Stcin ${ }^{14)}$. The enzyme solution was treated with bufferized resins for thirty minutes at $0^{\circ} \mathrm{C}$ in a test tube. After separation of resins by centrifugation or filtration, the enzyme was eluted from the resins with two $5.0 \mathrm{ml}$ portions of $0.2 \mathrm{M} \quad \mathrm{NaH}_{2} \mathrm{PO}_{4}-\mathrm{Na}_{2} \mathrm{HPO}_{4}$ buffer (pH 7.0 for Dxylose isomerase and $\mathrm{pH} 8.0$ for $\mathrm{L}$-arabinose isomer. ase). After adjustment of the $\mathrm{pH}$ of effluents to 7.0 or 8.0, the enzyme activity was determined.

\section{Chromatography on DEAE-Cellulose.}

CM- and DEAE-celluloses, Serva Products, were kindly supplied by Prof. Y. Morita, Kyôto University. Enzyme was applied on a $10 \sim 14 \mathrm{~cm} \times 0.8 \mathrm{~cm}$ column which contained about $0.5 \mathrm{~g}$ of DEAE-cellulose in equilibrium with the starting buffer. For most experiments, the initial buffer was $0.025 \mathrm{M}$ in respect to Tris concentration. Column was cooled by passing cold water at $2 \sim 4^{\circ} \mathrm{C}$ through a jacket tube. A gradient elution with $\mathrm{KCl}$ was carried out at a constants $\mathrm{pH}$. As a starting buffer, $100 \mathrm{ml}$ of $0.025 \mathrm{M}$ Tris buffer were placed in a mixing chamber (A). In another $100 \mathrm{ml}$ Erlenmyer flask (B), $100 \mathrm{ml}$ of the same buffer containing $\mathrm{KCl} 0.2$ or $0.4 \mathrm{M}$ were added. These are connected by a syphone of polyethylenc tubing $(0.4 \mathrm{~cm}$ internal diameter $)$, and the bottom 14) C. H. W. Hirs, S. Moore and W. H. Stein, J. Biol. Chem., 200, 493 (1953). 
of two flasks were kept at the same level and mixed by a magnetic stirrer. The flow rate through column was regulated at $0.5 \mathrm{ml}$ per minute, and effluent fractions of $20 \mathrm{ml}$ were collected. The optical density of each fraction was measured at $280 \mathrm{~m} \mu$.

\section{RESULTS AND DISCUSSIONS}

\section{Some Properties of Pentose Isomerases.}

Effects of temperature, $\mathrm{pH}$ and buffers on their activities and stabilities were determined as shown in Figs. 1 3 and in Table III. With ten minutes' incubation time, the optimum temperature was $45^{\circ} \mathrm{C}$ for both isomerases. In the presence of $10^{-3} \mathrm{M} \mathrm{MnSO}_{4}$, however, enzyme activities were strongly accelerated at higher temperatures and attained maximum at $60^{\circ} \mathrm{C}$. Manganese ions apparently served as a protective agent against thermal inactivation of the enzyme ${ }^{12)}$. In this experiment, activities were measured at $\mathrm{pH} 7.4$ for both isomerases after the preincubation at a temperature $10^{\circ} \mathrm{C}$ lower than the reaction temperature for five minutes. Optimum $\mathrm{pH}$ for activity was determined in ten minutes' in- cubation and found to be at $\mathrm{pH} 5.8 \sim 7.0$ for D-xylose isomerase, and at $\mathrm{pH} 7.8 \sim 8.0$ for L-arabinose isomerase. Effects of $\mathrm{pH}$ on enzyme stability were examined by incubating the enzyme at various $\mathrm{pH}$ 's at $20^{\circ} \mathrm{C}$ for 150 minutes. After adjusting pH's to 7.0 and 8.0 for $\mathbf{D}$-xylose isomerase and $\mathrm{L}$-arabinose isomerase respectively, remaining activities were determined and expressed as per cent of original activity. D-Xylose isomerase was most stable at $\mathrm{pH} 7.0 \sim 7.4$ and $\mathrm{L}$-arabinose isomerase at $\mathrm{pH}$ 8.2.

Furthermore, effects of buffers and of dilution of enzyme for stability were also determined. Enzyme was diluted 80 fold and stored at $0^{\circ} \mathrm{C}$ in $0.1 \mathrm{M} \mathrm{NaH} \mathrm{NO}_{4}-\mathrm{Na}_{2} \mathrm{HPO}_{4}$ or in $0.05 \mathrm{M}$ Tris buffer for 90 hours. D-Xylose isomerase was less stable in the phosphate buffer than in the Tris buffer, and the addition of cysteine could not prevent this inactivation.

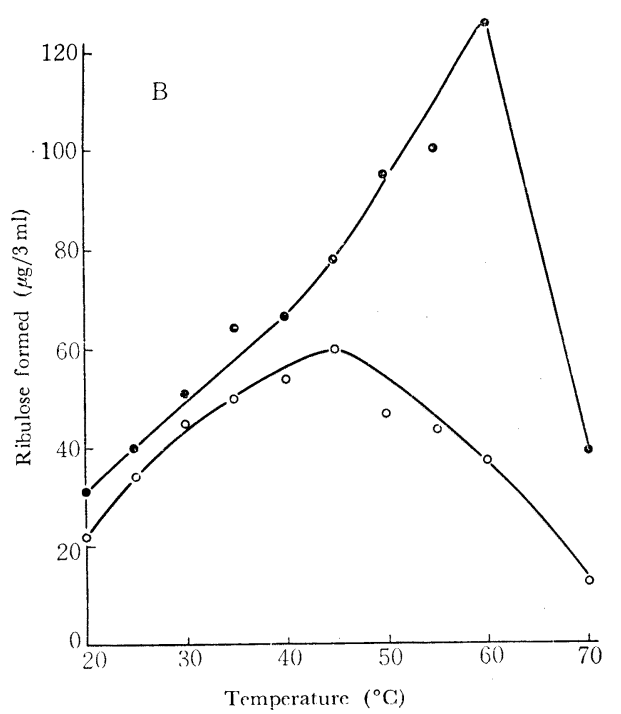

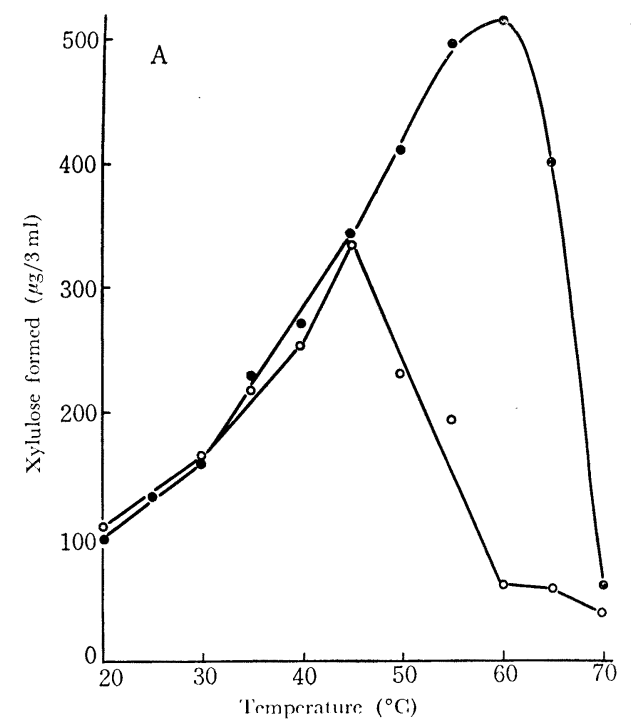

FIG. 1. Temperature-Activity Curve.
$\Lambda$. D-Xylose isomerase.
B. $\mathrm{L}$-Arabinose isomerase.
Reaction for $10 \mathrm{~min}$.
With $\mathrm{Mn}^{++}\left(10^{-3} \mathrm{M}\right)$ 

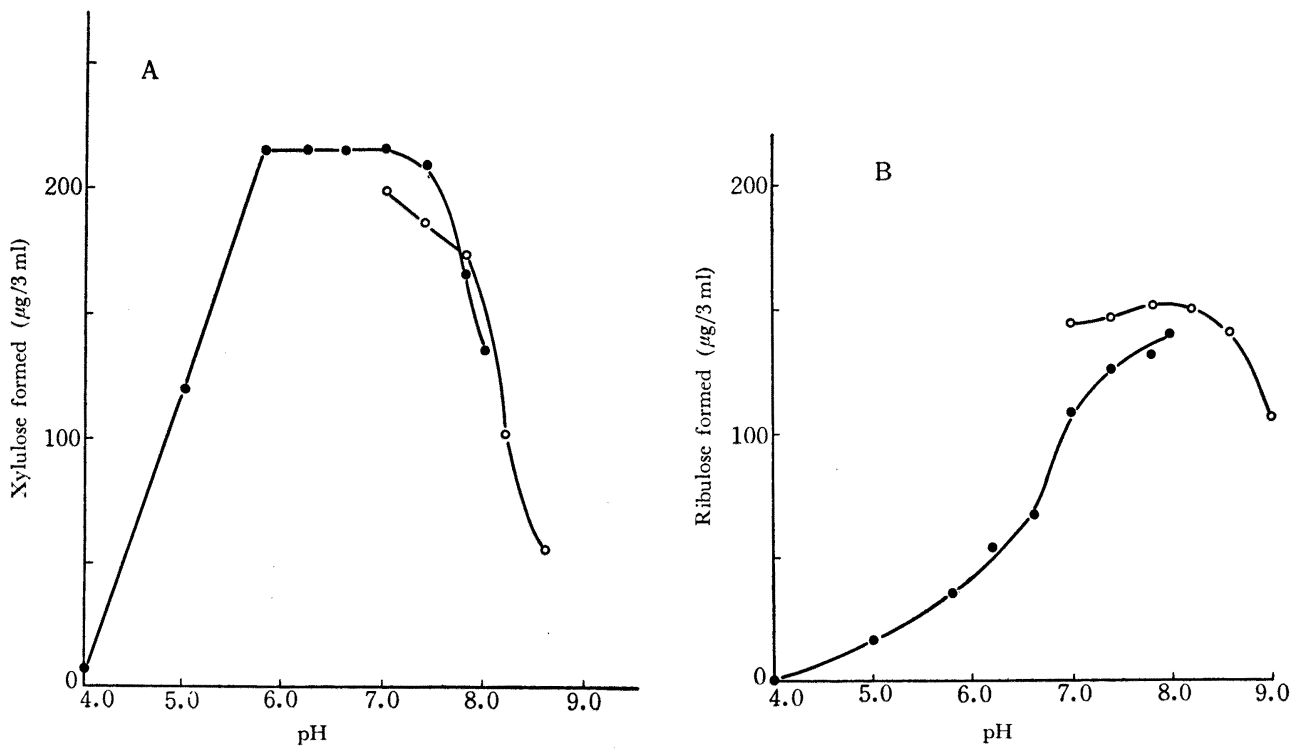

FIG. 2. pH-Activity Curve.

A. D-Xylose isomerase (Specific activity 52.5 , protein $22 \mu \mathrm{g} / 3 \mathrm{ml}$ ).

B. L-Arabinose isomerase (Specific activity 42.0 , protein $25 \mu \mathrm{g} / 3 \mathrm{ml}$ ). - O- Tris buffer,

Reaction at $37^{\circ} \mathrm{C}$ for $10 \mathrm{~min}$.
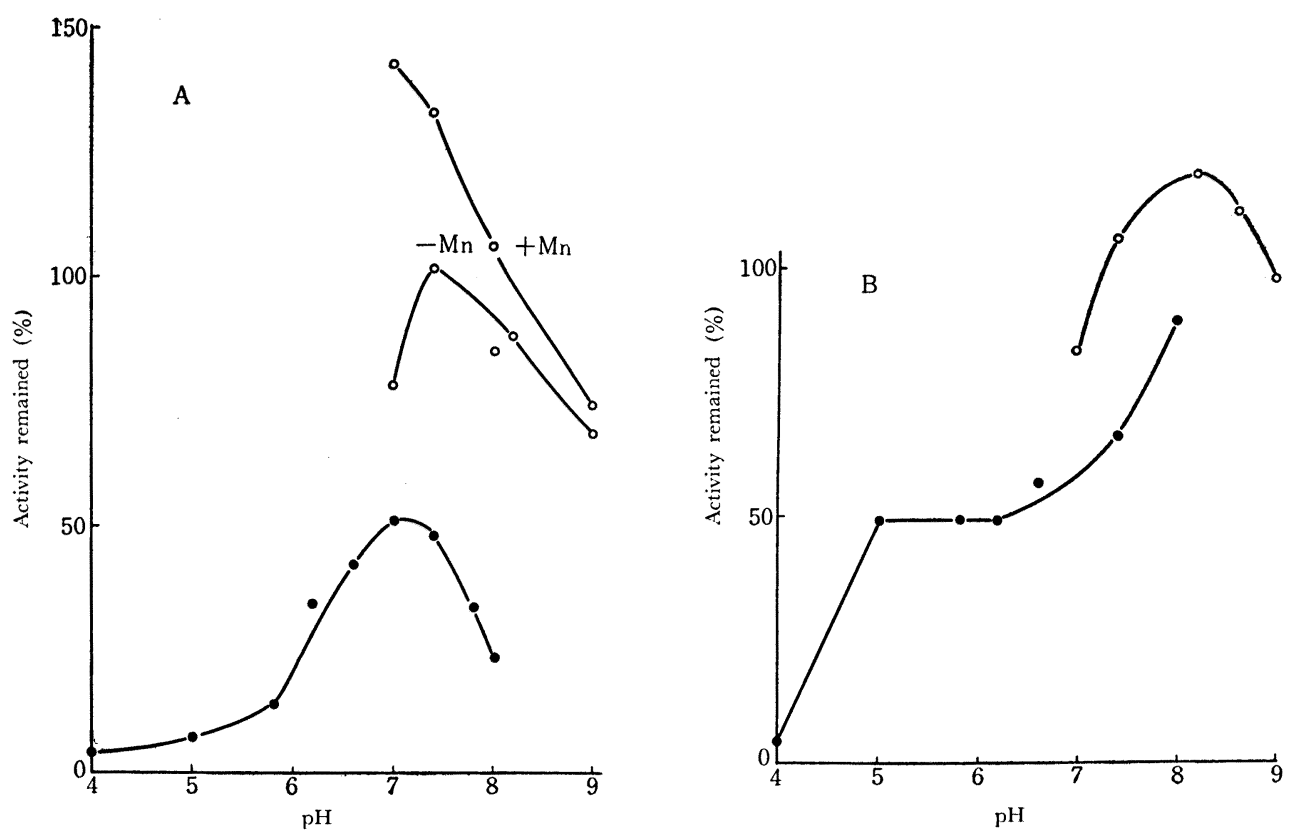

FIG. 3. pH-Stability Curve.

A. D-Xylose isomerase (Specific activity 58.4, protein $16.5 \mu \mathrm{g} / 3 \mathrm{ml}$ ).

B. L-Arabinose isomerase (Specific activity 42.0 , protein $25 \mu \mathrm{g} / 3 \mathrm{ml}$ ). - Tris buffer, - Mcllvain buffer.

Incubated at $20^{\circ} \mathrm{C}$ for $150 \mathrm{~min}$. 
TABLE III. EFFECTS ON STABILITY OF ISOMERASE

\begin{tabular}{|c|c|c|c|c|c|c|c|c|}
\hline \multirow[b]{3}{*}{ Incubation $\left(0^{\circ} \mathrm{C}, \mathrm{hr}.\right)$} & \multicolumn{8}{|c|}{ Activity remained } \\
\hline & \multicolumn{4}{|c|}{$\begin{array}{l}\text { D-Xylose isomerase } \\
\text { Xylulose formed, } \mu \mathrm{g} / 1.0 \mathrm{ml} \\
\text { enzyme solution }\end{array}$} & \multicolumn{4}{|c|}{$\begin{array}{l}\text { L-Arabinose isomerase } \\
\text { Ribulose formed, } \mu \mathrm{g} / 1.0 \mathrm{ml} \\
\text { enzyme solution }\end{array}$} \\
\hline & 0 & 2 & 18 & 44 & 0 & 18 & 42 & 90 \\
\hline $0.1 \mathrm{M} \mathrm{NaH} \mathrm{PO}_{4}-\mathrm{Na}_{2} \mathrm{HPO}_{4} 4.0 \mathrm{ml}$ & 121.5 & 112.5 & 87 & 57.6 & 253 & 201.5 & 203 & 173 \\
\hline$\prime \prime$ +cysteine $5 \times 10^{-4} \mathrm{M}$ & & 75.5 & 67.8 & 55.1 & & 255 & 205 & 173 \\
\hline $0.05 \mathrm{M}$ Tris $4.0 \mathrm{ml}$ & & 97.2 & 99.2 & 105.5 & & 205 & 202 & 176 \\
\hline$\prime \prime+\mathrm{MnSO}_{4} 10^{-3} \mathrm{M}$ & & 108.8 & 129 & 147 & & 240 & 208 & 168 \\
\hline + cysteine $5 \times 10^{-4} \mathrm{M}$ & & 92.8 & 111.4 & 125 & & 221 & 200 & 192 \\
\hline
\end{tabular}

Adsorption of Isomerases on Ion Exchange Resins.

As shown in Table IV, D-xylose isomerase was found to be adsorbed on Amberlite IRC-50 at $\mathrm{pH}$ 4.0. But column chromatography of the isomerase by this resin at $\mathrm{pH}$ 4.0 was unsuccessful because the enzyme was unstable at such an acidic pH. In one ex- periment, D-xylose isomerase (specific activity $51.3,1250 \mathrm{u})$ was adsorbed completely on a column $(0.8 \times 11 \mathrm{~cm})$ of this resin at $\mathrm{pH} 4.0$ and then the enzyme was eluted with $300 \mathrm{ml}$ of $0.2 \mathrm{M} \mathrm{NaH}{ }_{2} \mathrm{PO}_{4}-\mathrm{Na}_{2} \mathrm{HPO}_{4}$ buffer ( $\mathrm{pH} 7.0$ ) at a flow rate of $1.0 \mathrm{ml}$ per ten minutes. Most of the protein was recovered between 14 th to

TABLE IV. ADSORPTION ON ION EXchange REsins

A. D-Xylose isomerase

\begin{tabular}{|c|c|c|c|c|c|c|}
\hline \multirow[b]{2}{*}{ Enzyme } & \multirow{2}{*}{$\begin{array}{c}\text { Exchanger } \\
(500 \mathrm{mg})\end{array}$} & \multicolumn{5}{|c|}{ Activity recovered $(\%)$} \\
\hline & & $\mathrm{pH}$ & $\begin{array}{l}\text { Passed } \\
\text { solution }\end{array}$ & 1st eluate & 2nd eluate & Total \\
\hline $\begin{array}{l}\text { Total } 103 \mathrm{u} \\
\text { Protein } 2.3 \mathrm{mg} \\
\text { Specific activity } 55.7\end{array}$ & $\begin{array}{l}\text { Amberlite IRC-50 } \\
(200 \sim 400 \text { mesh })\end{array}$ & $\begin{array}{l}4.0 \\
5.0 \\
6.0 \\
7.0\end{array}$ & $\begin{array}{r}0.4 \\
76.0 \\
82.0 \\
84.7\end{array}$ & $\begin{array}{r}49.8 \\
7.4 \\
6.7 \\
10.5\end{array}$ & $\begin{array}{r}25.4 \\
2.4 \\
1.9 \\
3.0\end{array}$ & $\begin{array}{l}75.6 \\
85.8 \\
90.6 \\
98.2\end{array}$ \\
\hline $\begin{array}{l}\text { Total } 103 \mathrm{u} \\
\text { Protein } 2.1 \mathrm{mg} \\
\text { Specific activity } 49.1\end{array}$ & $\begin{array}{l}\text { Dowex-50 } \\
(200 \sim 400 \text { mesh })\end{array}$ & $\begin{array}{l}4.0 \\
6.0\end{array}$ & $\begin{array}{l}69 \\
95\end{array}$ & $\begin{array}{l}4.0 \\
5\end{array}$ & $\begin{array}{l}0 \\
0\end{array}$ & $\begin{array}{r}73 \\
100\end{array}$ \\
\hline $\begin{array}{l}\text { Total } 103 \mathrm{u} \\
\text { Protein } 2.3 \mathrm{mg} \\
\text { Specific activity } 55.7\end{array}$ & $\begin{array}{l}\text { Amberlite IRA-411 } \\
(100 \sim 200 \text { mesh })\end{array}$ & $\begin{array}{l}4.0 \\
5.0 \\
6.0 \\
7.0 \\
8.0\end{array}$ & $\begin{array}{l}43.4 \\
72.2 \\
76.6 \\
83.2 \\
51.5\end{array}$ & $\begin{array}{r}4.9 \\
10.6 \\
11.0 \\
10.0 \\
9.1\end{array}$ & $\begin{array}{l}2.0 \\
3.2 \\
3.7 \\
4.1 \\
4.7\end{array}$ & $\begin{array}{l}50.3 \\
86.0 \\
91.2 \\
97.3 \\
65.3\end{array}$ \\
\hline $\begin{array}{l}\text { Total } 103 \mathrm{u} \\
\text { Protein } 2.1 \mathrm{mg} \\
\text { Specific activity } 49.1\end{array}$ & $\begin{array}{l}\text { Dowex-2 } \\
(100 \sim 200 \text { mesh })\end{array}$ & $\begin{array}{l}4.0 \\
5.0 \\
6.0\end{array}$ & $\begin{array}{l}41.5 \\
69 \\
70.5\end{array}$ & $\begin{array}{r}9.0 \\
19.6 \\
17.4\end{array}$ & $\begin{array}{l}3.3 \\
6.4 \\
5.8\end{array}$ & $\begin{array}{l}53.8 \\
95.0 \\
93.7\end{array}$ \\
\hline $\begin{array}{l}\text { Total } 96.2 \mathrm{u} \\
\text { Protein } 1.65 \mathrm{mg} \\
\text { Specific activity } 58.4\end{array}$ & $\begin{array}{l}\text { CM-cellulose } \\
(50 \mathrm{mg})\end{array}$ & $\begin{array}{l}4.0 \\
5.0 \\
6.0 \\
7.0\end{array}$ & $\begin{array}{l}15.3 \\
64 \\
81.8 \\
77.4\end{array}$ & $\begin{array}{r}26.6 \\
6.5 \\
5.7 \\
5.0\end{array}$ & $\begin{array}{l}- \\
-\end{array}$ & $\begin{array}{l}42.9 \\
70.5 \\
87.5 \\
82.4\end{array}$ \\
\hline L-Arabinose isom & & & & & & \\
\hline $\begin{array}{l}\text { Total } 66.2 \mathrm{u} \\
\text { Protein } 1.7 \mathrm{mg} \\
\text { Specific activity } 40.3\end{array}$ & $\begin{array}{l}\text { Amberlite IRC-50 } \\
(200 \sim 400 \text { mesh })\end{array}$ & $\begin{array}{l}4.0 \\
5.0 \\
6.0 \\
7.0\end{array}$ & $\begin{array}{r}0.2 \\
29.1 \\
33.4 \\
42.5\end{array}$ & $\begin{array}{r}35.7 \\
8.5 \\
4.2 \\
5.0\end{array}$ & $\begin{array}{r}14.4 \\
3.1 \\
1.3 \\
1.9\end{array}$ & $\begin{array}{l}50.3 \\
40.7 \\
38.9 \\
49.4\end{array}$ \\
\hline
\end{tabular}


20th tubes, but yield of the enzyme activity was only 2.5 per. ecnt of the original activity, and the further elution was useless.

\section{Column Chromatography on DEAE-Cellulose.}

From the above results, it was thought to be desirable to run chromatography at a neutral or slightly alkaline $\mathrm{pH}$ for pentose isomerases. For this purpose, DEAE-cellulose seemed to be the most useful. D-Xylose isomerase (specific activity 32.5, $745 \mathrm{u}$ ) was adsorbed completely on DEAE-cellulose which was previously equilibrated with $0.01 \mathrm{M}$ $\mathrm{NaH}_{2} \mathrm{PO}_{4}-\mathrm{Na}_{2} \mathrm{HPO}_{4} \quad(\mathrm{pH}$ 7.0). When a column was washed successibly with each $50 \mathrm{ml}$ of $0.01 \mathrm{M}, 0.02 \mathrm{M}$ and $0.05 \mathrm{M}$, and each $100 \mathrm{ml}$ of $0.1 \mathrm{M}$ and $0.2 \mathrm{M}$ of the same buffer $(\mathrm{pH} 7.0)$, the enzyme was eluted with $0.1 \mathrm{M}$ buffer, but recovery of the enzyme was still only 22.1 per cent owing to the unstable nature of enzyme in phosphate buffer. Elution of the enzyme with Tris buffer by stepwise elution method with increased $\mathrm{KCl}$ molarity recovered 75 per cent of the activity, but the enzyme activity appeared in two or more peaks. Similarly, L-arabinose isomerase was also found in two peaks by stepwise elution. Therefore the gradient elution

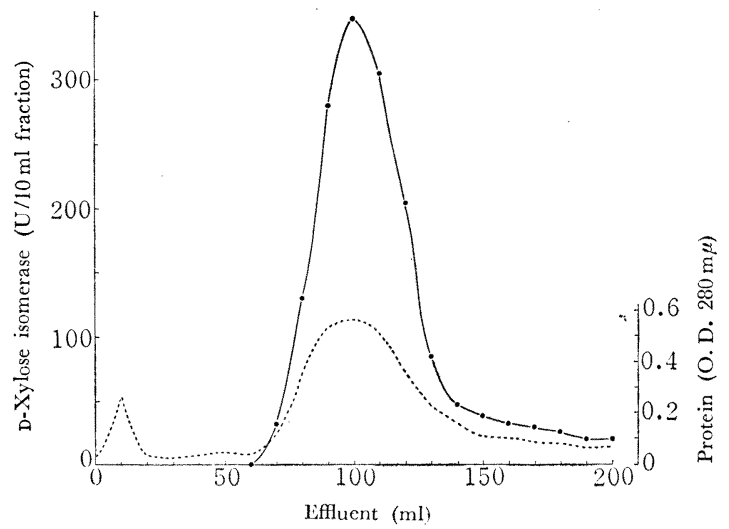

FIG. 4. Column Chromatography of D-Xylose Isomerase on DEAE-Cellulose.

- - D-Xylose isomerase, ....... Protein

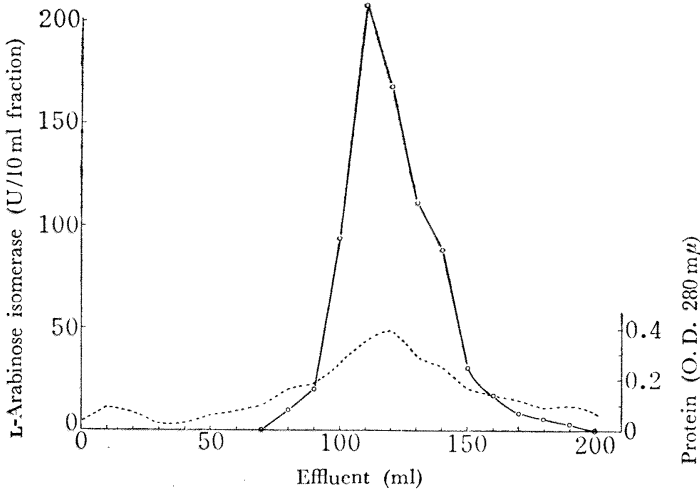

FIG. 5. Column Chromatography of L-Arabinose Isomerase on DEAE-Cellulose.

-O- L-Arabinose isomerase, ....... protein

method was applied. Typical elution patterns are shown in Figs. 4 and 5. D-Xylose isomerase $(1600 \mathrm{u})$ and $\mathrm{L}$-arabinose isomerase $(910 \mathrm{u})$ were applied and 88 and 85 per cents respectively of the original activities were recovered. Eluted fractions were collected and dialyzed against $0.025 \mathrm{M}$ Tris buffer ( $\mathrm{pH} 7.4$ ) containing $5 \times 10^{-3} \mathrm{M}^{\mathrm{MnSO}_{4}}$. However, dialysis against the same buffer without addition of $\mathrm{MnSO}_{4}$ caused the inactivation of the enzyme, i.e. the activity was diminished to about one half to one third. The addition of pyridoxol, pyridoxal, pyridoxamine, nicotinamide, $p$ aminobenzoate, biotin, FMN or FAD (each $400 \mu \mathrm{g}$ ) with $10^{-3} \mathrm{M}$ of $\mathrm{MnSO}_{4}$ to the inactivated enzyme preparations did not reactivate the enzyme.

Substrate Specificity and Metal Requirement.

Purified enzyme preparations exhibited a maximal absorption spectrum at $280 \mathrm{~m} \mu$ (Fig. 6 ), and showed high specificity on the respeciive substrates. Except corresponding aldopentoses and their ketoses, no other ketoses were produced from the corresponding pentoses, hexoses or sugar alcohols. So it was assumed that the two pentose isomerases were different enzymes. L-Arabinose isomerase was activated by $\mathrm{Mn}^{++}$or $\mathrm{Co}^{++2,12)}$. Further 


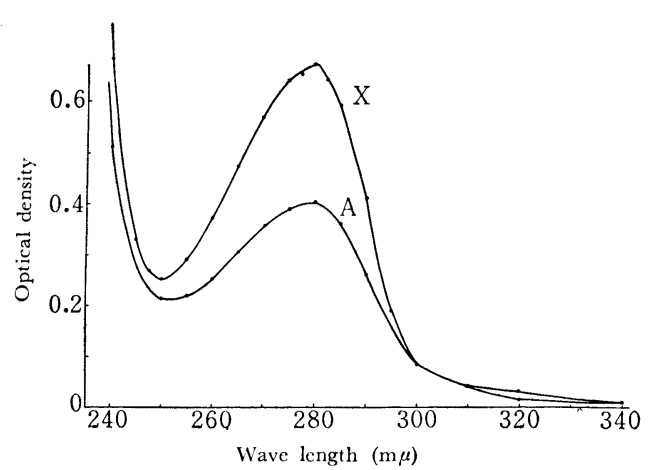

FIG. 6. UV-Spectrum of Purified Pentose Isomerases. $\mathrm{X}$. D-Xylose isomerase, A. L-Arabinose isomerase.

Table V. Substrate Specificity on Pentose ISOMERASE

$\begin{array}{lcc}\text { Isomerase } & \begin{array}{c}\text { D-Xylose iso- } \\ \text { merase }\end{array} & \begin{array}{c}\text { L-Arabinose iso- } \\ \text { merase }\end{array} \\ \text { Specific activity } & 78.2 & 132.0 \\ \text { Protein used }(\mu \mathrm{g} / \text { tube) } & 15.5 & 13.0 \\ \text { Substrate }(20 \mu \text { moles) } & \begin{array}{c}\text { Ketose formed } \\ 10 \text { min. }\end{array} & \begin{array}{c}\text { (or decreased) in } \\ \text { a }\end{array} \\ \text { D-Xylose } & 156 & 0 \\ \text { D-Xylulose } & -165 & 0 \\ \text { L-Xylose } & 0 & 0 \\ \text { L-Arabinose } & 0 & 205 \\ \text { L-Ribulose } & 0 & -250 \\ \text { D-Arabinose } & 0 & 0 \\ \text { D-Ribose } & 0 & 0 \\ \text { L-Rhamnose } & 0 & 0 \\ \text { Glucose } & 0 & 0 \\ \text { Mannose } & 0 & 0 \\ \text { Galactose } & 0 & 0 \\ \text { Mannitol } & 0 & 0 \\ \text { Sorbitol } & 0 & 0 \\ \text { Dulcitol } & 0 & 0\end{array}$

observations were carried out on these purified enzyme preparations after EDTA-treatment as described in the previous paper ${ }^{12)}$. When the enzyme was treated with more concentrated solutions of EDTA (over $5 \times 10^{-3} \mathrm{M}$ ) or after prolonged dialysis (20 hours), it was inactivated irreversibly.

After dialysis of the enzyme in the presence of $2.5 \sim 5 \times 10^{-3} \mathrm{M}$ EDTA against $0.025 \mathrm{M}$ Tris buffer at $5^{\circ} \mathrm{C}$ for 20 hours, the enzyme was almost completely inactivated, but the activity was fully restored after addition of $\mathrm{MnSO}_{4}$. Addition of cobaltous, magnesium, strontium, calcium, barium, ferric or zinc ions showed only little recovery of activities. So it was concluded that both pentose isomerases are $\mathrm{Mn}^{++}$-catalyzed enzymes.

\section{SUMMARY}

Properties of both pentose isomerases are:

\begin{tabular}{|c|c|c|}
\hline & $\begin{array}{l}\text { D-Xylose } \\
\text { isomerase }\end{array}$ & $\begin{array}{l}\mathrm{L} \text {-Arabinose } \\
\text { isomerase }\end{array}$ \\
\hline $\begin{array}{l}\text { Temperature } \\
\text { optimum }\end{array}\left\{\begin{array}{l}\text { without } \mathrm{MnSO}_{4} \\
\text { with } \mathrm{MnSO}_{4}\end{array}\right.$ & $\begin{array}{l}45^{\circ} \mathrm{C} \\
60\end{array}$ & $\begin{array}{l}45^{\circ} \mathrm{C} \\
60\end{array}$ \\
\hline pH optimum & $5.8 \sim 7.0$ & $7.8 \sim 8.0$ \\
\hline $\mathrm{pH}$ for stability & $7.0 \sim 7.4$ & 8.2 \\
\hline
\end{tabular}

Both isomerases were purified with DEAEcellulose using a gradient elution technique, increasing $\mathrm{KCl}$ concentration at a constant $\mathrm{pH}$ in a Tris buffer.

Purified enzymes showed high specificity for

TABLE VI. REQUiREMENT OF METAL

\begin{tabular}{|c|c|c|c|c|}
\hline Metal & \multicolumn{4}{|c|}{$\begin{array}{l}\text { D-Xylose isomerase } \\
\text { Xylulose formed }(\mu \mathrm{g} / 3 \mathrm{ml})\end{array}$} \\
\hline (Final, M) & 0 & $10^{-5}$ & $10^{-4}$ & $10^{-3}$ \\
\hline $\mathrm{MnSO}_{4}$ & 0 & 4.5 & 25.6 & 250.0 \\
\hline $\mathrm{CoCl}_{2}$ & & 0 & 2.6 & 37.1 \\
\hline $\mathrm{MgSO}_{4}$ & & 3.8 & 7.7 & 15.4 \\
\hline $\mathrm{SrCl}_{2}$ & & 0 & 0 & 0 \\
\hline $\mathrm{CaCl}_{2}$ & & 2.6 & 0 & 7.7 \\
\hline $\mathrm{BaCl}_{2}$ & & 0 & 0 & 2.6 \\
\hline $\mathrm{FeSO}_{4}$ & & 0.6 & 3.8 & 10.2 \\
\hline $\mathrm{ZnSO}_{4}$ & & 0 & 4.5 & 13.4 \\
\hline $\mathrm{MnSO}_{4}{ }^{*}$ & 256 & & & 259 \\
\hline
\end{tabular}

\begin{tabular}{ccccc}
\multicolumn{5}{c}{ L-Arabinose isomerase } \\
Ribulose formed $(\mu \mathrm{g} / 3 \mathrm{ml})$ \\
\hline 0 & $10^{-5}$ & $10^{-4}$ & $10^{-3}$ & $5 \times 10^{-3}$ \\
11.8 & 16.6 & 26.9 & 83.2 & 117 \\
& 13.4 & 21.8 & 25.6 & 25.6 \\
& 14.7 & 15.7 & 28.8 & 33.3 \\
& 14.1 & 20.5 & 30.7 & 25.0 \\
& 14.7 & 14.1 & 26.3 & 23.7 \\
& 16.0 & 16.6 & 32.0 & 33.3 \\
& 17.3 & 16.0 & 26.8 & -- \\
& 19.2 & 17.3 & 11.5 & 17.9 \\
& & & 105.6 &
\end{tabular}


their substrates and metal requirements.

Acknowledgments. The author wishes to express his gratitude to Emeritus Prof. H. Katagiri, Kyôto University, for his constant interest and encouragement. He also wishes to acknowledge his indebtedness to Prof. K. Kita- hara, the Institute of Applied Microbiology, University of Tôkyô and to Profs. T. Hata and Y. Morita, the Research Institute for Food Science, Kyôto University for valuable advices on chromatography. 